\title{
BUSINESS DIGITALIZATION AS A FACTOR OF GOVERNANCE MODERNIZATION
}

\author{
Somdech Rungsrisawat \\ Suan Sunandha Rajabhat University, Bangkok, Thailand
}

The study takes a new paradigm of state business regulation, based on the synchronization of interests of business, state and society, on the defining the principles of Government participation in the global economic processes. As a tool for business consolidation, improving the efficiency of state regulation, the formation of e-government was considered. The paper characterizes the e-government as a new form of state regulation of economy. The factors of effective e-government implementation strategy were analyzed. The experience of digitalization of governmental functions of modern states, the rates of asynchrony of development of electronic government in the world, relating with the economic efficiency of modern states, were considered.

Keywords: business, international economy, ICT, innovative, digitalization, business process

\section{Introduction}

The formation of globally competitive national economy, which is effectively adapted to the world economic trends, is based on the optimal ways of business, government and society interactions. It requires the quality of administration rising, the modernization of economy regulation, the development of foreign policy, based on the new information and communication technologies.

The main infrastructure components for improving the government regulatory competences in the economic sphere, is e-government. This is, on the one hand, the result of the modern information technologies introduction in the global economic processes, on the other hand, the transformer of classical interactions in the global economic system, impacting on such institutions as the global competition, the international division of labor, international trade and many others.

The level of Government regulatory structures informatization in the world economy is traditionally lower than in business - both in terms of their computer hardware means, software and staff access to the Internet.

In this connection, on the background of the obvious advantages of strategy of digitalization of economic regulation implementing, the problems of studying of transformations, encouraged by e-government introduction, of mechanisms for implementing

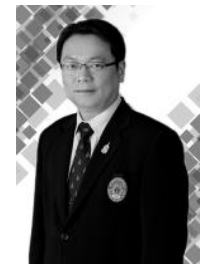

\section{Somdech Rungsrisawat}

PhD, ast. professor, Vice-President for Academic Affairs, Suan Sunandha Rajabhat University, Bangkok, Thailand Published more than 35 research papers on management, human resource management, business organization, digitalization and economy's innovative development.

Realized number of nationally granted research projects, member of editorial boards in international peer-reviewed journals and international conferences 
e-government strategy and their implications for the globalizing world economy, seem timely.

The scientific hypothesis of the research is based on the needs of state regulation of the economy innovative modernizing to ensure the long term growth of national economies competitiveness in the global economy structure. Which can be achieved by improving the quality of government economic regulation, by optimizing the interaction of e-business, society and government, by improving the social responsibility of e-business in terms of actual problems?

The purpose of the study is, based on the best practice of e-government strategies implementation, on analysis of indicators of today's states readiness to their governmental economic functions digitalization, of the prospects of international constructs of economic regulation development; to determine the principles and tools of innovative modernization of the structure of e-business Government regulation.

This purpose achieving provides a logical sequence of the following tasks:

- to analyze the modern transformations of principles of foreign economic activities regulation; determined by transnationalization and by the global trend of innovative modernization;

- to identify the main characteristics, inherent to present stage of world economic development requirements;

- to analyze the effectiveness of informatization and net-working, as guidelines for world economy controlling;

- to characterize the electronic government as an infrastructure of public economic regulation innovative modernization;

- to consider the sources, the domestic and foreign economic spheres manifestations of e-government economic efficiency;

- to identify the stages of the strategy of government functions digitalization in the global economy;

- to conduct quantitative and qualitative analysis of the rate of economic regulation innovative modernization in the modern world;

- to examine the forming e-government experience, the main factors, limiting the regulatory functions of the state in economic digitizing;

- to identify the principles, guidelines of infrastructure of state regulation of e-business in the modern world forming.

\section{Background}

Researches of the e-government development, of their implementation in the global economic governance system, as well as analysis of the institutional and infrastructural transformations, stimulated by Government regulatory competence digitalization, were the subject of contemporary scholars numerous works.

The issues of mechanisms and instruments of economic regulation transformations under the influence of the global trend of innovative modernization, of the information economic models formation researched by Lenihan, D. (2002), Rayner, J. (2006), Howlett, M. (2006), Ivanov, D. (2004), Vainstein, G. (2002).

Atkinson, R. (2003), Dunleavy, P. (2005), Kjaer, A. (2004), Leigh, A. (2003), McDermott, K. (2006), Margetta, H. (2005), Pierre, J. (2000) defined e-government as an 


\section{BUSINESS DIGITALIZATION AS A FACTOR}

infrastructure of Government innovative modernization, its levels, structure and economic efficiency.

Analysis of the e-government strategy theoretical basis and practical enforcement, that satisfies both the external economic environment and internal capabilities of modern macroeconomic systems requirements, were carried out by Bellamy, K. (2002), Camp, J. (2000), Matilla, J. (2003), Shimko, P. (2002).

Today's national economic systems readiness to implement e-government strategy evaluations became the object of study of Chien, Y. (2000), Chadwick, A. (2003), Moshkin, I. (2006) and expert teams of international economic organizations - the World Trade Organization, the World Bank and specialized agencies.

Theoretical base of the study were approaches and methods of classical political economy (world trade theories and fundamental principles of foreign economic cooperation between the countries), Marxist economic theory (economic division of the world, the expansion of capital as the pattern of world development), the neoclassical school (the formation of competitive advantages in the manufacturing industry) and institutional economics (on the organizational of economic relations, based on networking).

Using these conceptual positions as starting positions, made possible to achieve the effect of different methodological approaches complementarily, while maintaining the integrity of the chosen scientific hypothesis.

Methodological foundation for research. We used the provision of the system approach and system analysis in the unity of the historical, genetic and functional-structural aspects; the scientific methods of ascent from the abstract to the concrete, of logical and historical unity, of analysis and synthesis, extrapolation, as well as methods of economic researches: economic and statistical groupings, conceptual modeling, typological clustering and logical design.

\section{The Modern Countries in the Global Process of Governance Digitilization}

It is now possible to highlight the several steps in the e-government concept implementation; these are so-called stages of the traditional government transformation to electronic: the presence on the Internet, on-line interactions, transactions (deals) in electronic form conduction and complete transformation.

In the first phase, informative functions of government implement. It seems the government regulation qualitative growth, and is carried out by public authorities through the web-sites, thus creating the technical basis for networking with citizens and organization development, the legal framework for placing information on the Internet.

The next stage is the development of technologies for authorities interactive with the civil society (G2P). The tax declarations submission, purchases of goods for state needs, etc. are translated into an electronic and virtual sphere.

With the transaction in electronic forms implementation, the transaction to a documentary information environment interaction is completed. It allows to legally recognizing the equivalence of electronic form transactions, the paperless government regulation introduction. Complete traditional governance transformation in e-government is the final stage of full ICT integration in the management processes.

The state regulation of economy modernization, becoming a global process, is differ of structural and content indicators, due to the fact that countries involved in the modernization 
of economic relations process, being at different levels of their socio-economic development, having its distinctive characteristics and performance.

Table 1 - The types of countries, depending on their positioning in the global process of governance digitizing

(made by the author)

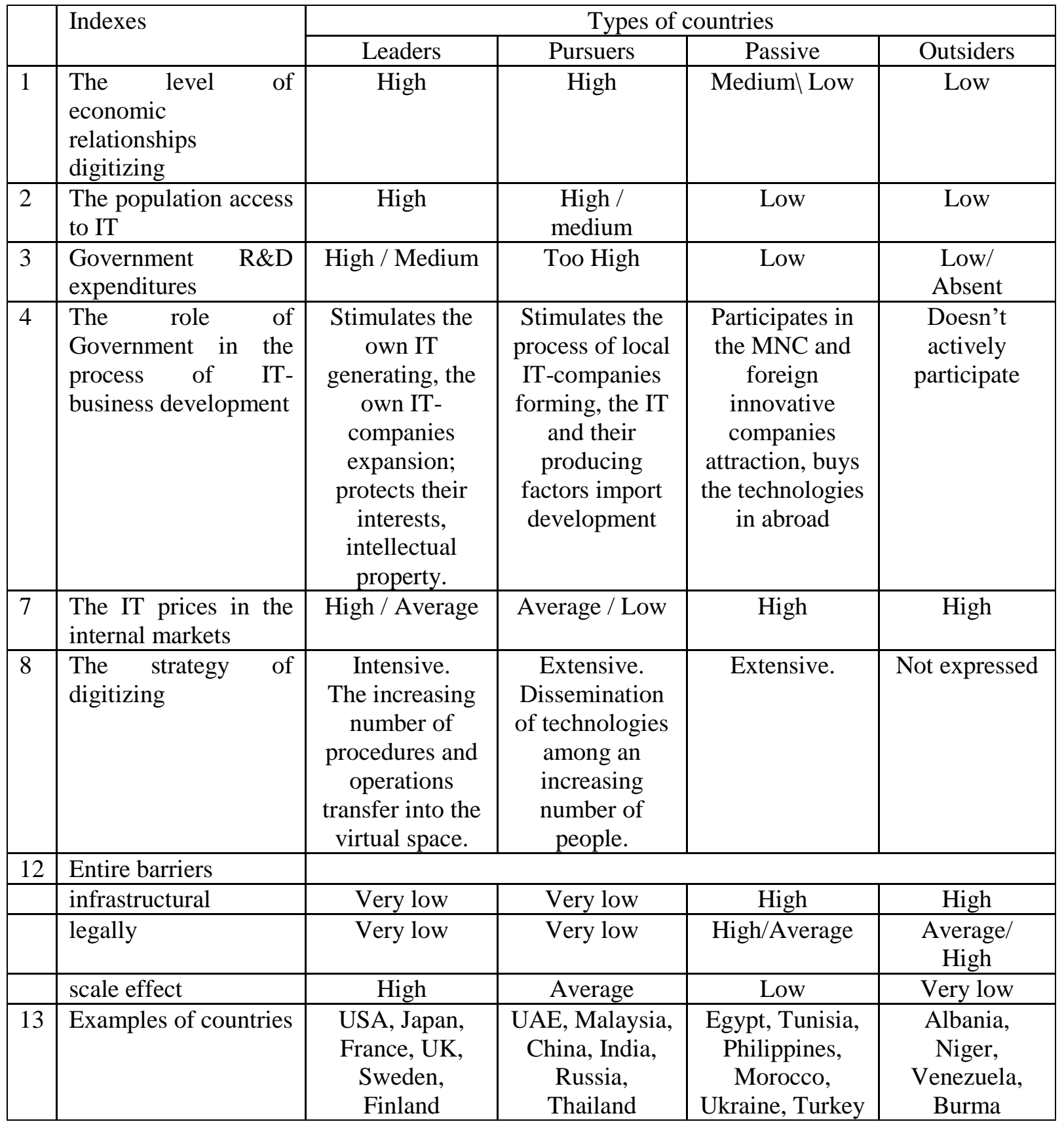

The analysis of static and dynamic transformation process of state regulation parameters in the various regions of the world for the last 15-20 years, allowed to identify four groups of national economies, which differ on a number of criteria for the state 


\section{BUSINESS DIGITALIZATION AS A FACTOR}

regulation, the role of information technology in the implementation of government regulatory competence, the business, government and people relationships to the information and virtualization of the social relations process (Table 1).

Based on the fact that the macro-economic systems in the global economy positioning without taking into account degrees of their governments regulatory competence digitalization, can not form a complete picture, determine the competitive economic models origins, to identify trends in their participation in the world economies self-developing system, an assessment of country conditions for e-government strategies implementation and their effectiveness were made (Table 2).

Table 2 - The index of government economic functions digitalization, $2008-2016$

(Source: United Nations e-Government Survey 2016. From e-Government to Connected Governance / Department of Economic and Social Affairs. Division for Public Administration and Development Management. New York, 2017)

\begin{tabular}{|l|c|c|c|c|c|c|}
\hline \multirow{2}{*}{ Country } & \multicolumn{2}{|c|}{2016} & \multicolumn{2}{c|}{2012} & \multicolumn{2}{c|}{2008} \\
\cline { 2 - 7 } & Index & Rate & Index & Rate & Index & Rate \\
\hline Sweden & 0,9157 & 1 & 0,8983 & 3 & 0,8741 & 4 \\
\hline Denmark & 0,9134 & 2 & 0,9058 & 2 & 0,9047 & 2 \\
\hline Norway & 0,8921 & 3 & 0,8228 & 10 & 0,8178 & 10 \\
\hline USA & 0,8644 & 4 & 0,9062 & 1 & 0,9132 & 1 \\
\hline Netherlands & 0,8631 & 5 & 0,8021 & 12 & 0,8026 & 11 \\
\hline Korea S. & 0,8317 & 6 & 0,8727 & 5 & 0,8575 & 5 \\
\hline Canada & 0,8172 & 7 & 0,8425 & 8 & 0,8369 & 7 \\
\hline Australia & 0.8108 & 8 & 0.8679 & 6 & 0.8377 & 6 \\
\hline France & 0,8038 & 9 & 0,6925 & 23 & 0,6687 & 24 \\
\hline UK & 0,7872 & 10 & 0,8777 & 4 & 0,8852 & 3 \\
\hline Japan & 0,7703 & 11 & 0,7801 & 14 & 0,7260 & 18 \\
\hline Belarus & 0,5213 & 56 & 0,5318 & 51 & 0,4888 & 58 \\
\hline Kuwait & 0,5202 & 57 & 0,4431 & 75 & 0,3649 & 101 \\
\hline Russia & 0,5120 & 60 & 0,5329 & 50 & 0,5017 & 52 \\
\hline Venezuela & 0,509 & 62 & 0,5161 & 55 & 0,4898 & 56 \\
\hline
\end{tabular}

As demonstrated by the results of different countries evaluation, the e-government levels are different. The strategies of government functions in economic management and social structure digitalization are asynchronous.

The evaluation has shown, that the budget investment increasing does not always determine the government services quality increasing and the society costs of its consumption reducing.

On the one hand, society should be prepared to e-government strategy implement there must be the corresponding demand for digital services, the public confidence to them, and of course, the infrastructure, adapted to the level of society development and to the modernizing of government ambitions.

Also, the e-government strategy implementation calls for existing legal and administrative infrastructure modernization - the making a certain adjustments to the current 
legislation, the adjustment of public employees, enhance their skills and the degree of compliance with increased requirements in working with digital control systems.

Finally, e-government, as an important step towards transparent economy, in any case will face a whole set of constraints - from government officials corrupt to "out of the shadows" failure of the business community.

One of the main problems of the electronic government global implementation, which also requires an immediate solution, - is the digital divide. It includes the low literacy and the lack of information skills of most of the population, the existing information systems orientation on the needs of wealthy individuals, the communication channels weakness, especially in the countryside.

Therefore, the support for the so-called e-participation remains a priority for egovernment building, and therefore the e-participation concept should also imply the all citizens inclusion in the information society, the efficient and transparent services for all citizens ensuring, the effective management of information and its providing for all citizens, the citizens familiarizing with the information society advantages, the social and cultural equality creating.

The prospects of public services portals development associated with the needs to develop the regulatory frameworks, in particular, the public services and administrative regulations legislation on standards. The national and municipal government improvement, the new economy construction, requires the development of electronic information exchange between the structures of government, business and civil society. For this, the paper forms and documents monopoly should be excluded from the legislation.

For the training to work with a modern information technology, need to actively develop the information literacy centers, the retraining programs, with specialized universities and colleges. As a good stimulus for the "electronic government" formation should be the inclusion of the government digitalization level into a set of criteria for effectiveness of regional or national leadership evaluation.

It may be noted that the "electronic government" is inevitability, a sign of modern culture, of civilization. And modern States must pass the way of "electronic government" formation, because another way to increase the national competitiveness, the efficiency of the macroeconomic system integration in the world economic structure is absent.

\section{Solutions and Recommendations}

As the most significant scientific results of the research are the following results.

1. In the globalization context the government capacity to regulate the economy and the businesses ability for self-regulation have been greatly undermined. The maintenance of this situation in the G2B sphere, the trend of liberalization and globalization deepening, promoted by business, on the background of government attempts to regulate the global economy through the market-based instruments, will contribute to reducing the world economy cycles time and to increase their extremes, will make the coming crisis less predictable and easily transformable to global.

2. For avoiding the extreme measures, for preserving own importance and priority in the goals for further economic development setting, the modern governments need today to review the general principles of foreign economic control, and to create a modern, conforming to the scientific and technical progress, infrastructure for implementing their 


\section{BUSINESS DIGITALIZATION AS A FACTOR}

regulatory competencies. The new economic regulation doctrine should be based on the recognition of the important role in development of two more, in addition to government, actors - business and society, whose interests are fundamentally different both in the short term, and in the strategic vision.

3. In the global economy, the government must realize, first and foremost, the interests of domestic business as the most active, creative and aggressive elements of society, strongly supporting and guiding its expansion, considering it as one of the key instruments of national economic development and welfare. Inside their own society, government must support the people with its desire for justice and for more equitable resources distribution.

4. Sustainable economic progress in a complex system of world economic relations requires from the modern government to develop a set of measures, aimed at consolidating the domestic business. The businesses ability to form the transnational constructs of inputs and finished products distribution, is segmenting the national economy, by creating within the macroeconomic system the complex of autonomous "strategic business zones", which are a weakly regulated by government due to the networking effects. As the condition of business consolidation, competitiveness of domestic production improving has to become a new concept of market-based government functions, of public management, which infrastructure is, first and foremost, e-government.

5. E-government, is generally defined as a government information influence with citizens and organizations with ICTs, networking and the Internet using, based on the principles of "service state", is strategically focused on external competitiveness of the national economy improving through the effectiveness of state influence measures increasing, the costs for their implementation reducing. In parallel, a range of problems, related to the government services provision, public procurement, investment attractiveness, liberalization of foreign economic activity are solving; an additional resource for the public policy development is forming; the options for integration into the structure of world economy, into the international division of labor are identifying.

6. The historical experience of e-government building in Western countries, in the Asia-Pacific region analysis allowed, on the one hand, the modern macro-economic systems classification, depending on the pace of state regulation innovation and modernization. On the other, by identifying the common patterns and stages of the government functions in economy digitalization. In terms of e-government implementation - from the government presence on-line through the government web-sites transformation to the interactive structure having the opportunity to commit the transaction, to their unification into a single Government portal, we can determine the conditions for effective e-government strategy implementation, to consider them in conjunction with the government measures, eliminating the governance digitalization limitations, which are related to the legal infrastructure weakness, to the problems of information and communication technologies coverage and to the weakness of activities of public authorities transparency.

7. The intensifying of the "electronic government" formation, of its incorporation into the nascent global economic regulation infrastructure, requires the adoption of measures, aimed both at the authorities, and at potential electronic services users - corporate and consumer segments of the economy, the regulatory framework development (public service standards and administrative regulations, the electronic documents and electronic interaction between authorities and consumers of public services legalization), the development of centers of information literacy in the retraining programs. 


\section{References :}

Atkinson, R., Leigh, A. (2003). Customer-oriented e-government: Can we ever get there? In Gurtin, G., Sommer, M., (2003). The World of E-Government (pp. 80-98). Binghampton, NY: Haworth Press.

Bellamy, C. (2002). From automation to knowledge management: modernizing British government with ICTs. International Review of Administrative Sciences. Vol. 68. № 1.

Bogdanovskaya, I. (2004). E-governance. Social sciences and modernity, № 6.

Camp, J., Chien, Y.T. (2000). The Internet as Public Space: Concepts, Issues, and Implications in Public Policy. Computers and Society. № 4.

Chadwick, A., May, C. (2003). Interaction between States and Citizens in the Age of the Internet: "eGovernment" in the United States, Britain, and the European Union. Governance: An International Journal of Policy, Administration, and Institutions. Vol. 16. № 2.

Dunleavy, P., Margetta, H., Bastow, S., Tinkler, J. (2005). New Public Management is Dead - Long Live Governance. Journal of Public Administration Research and Theory. Vol. 16. № 3.

Elyakov, A. (2004). Informational type of social inequity. Social researches, № 8.

Hajer, M., Wagenaar, H. (2003). Deliberative Policy Analysis: Understanding Governance in the Network Society. Cambridge: Cambridge University Press.

Hou ,Y., Moynihan, D. (2007). The Case for Countercyclical Fiscal Capacity. Journal of Public Administration Research and Theory. Vol. 17. № 2.

Howlett, M., Rayner, J. (2006). Globalization and Governance Capacity: Explaning Divergence in National Forest Programs as Instances of "Next-Generation" Regulation in Canada and Europe. Governance. Vol. 19. № 2.

Ingraham, P. (2005). Performance: Promises to Keep and Miles to Go. Public Administration Review. Vol. 65. № 4.

Ivanov, D. (2004). The society as a virtual reality. Moscow: AST.

Jaeger, P. (2005). Deliberative democracy and the conceptual foundations of electronic government. Government Information Quarterly. Vol. 22. № 3.

Kjaer, A. (2004). Governance (Key Concepts). Cambridge, UK, Malden, MA: Polity Press.

Lenihan, D. (2002). E-Government, Federalism, and Democracy: The New Governance. Ottawa: The Centre for Collaborative Government.

Matilla, J. (2003). Participatory e- Governance - A new solutions to an old problem? In: Salminan, A. (2003). Governing Networks. Amsterdam: IOS Press.

McDermott, K. (2006). Incentives, Capacity, and Implementation: Evidence from Massachusetts Education Reform. Journal of Public Administration Research and Theory. Vol. 16. № 1.

Moshkin, I. (2006). The e-business evolution: categorical analyses. Economic herald of Rostov State University, № 3.

Pierre, J., Peters, G. (2000). Governance, Politics and the State. Political Analysis. N.Y.: St. Martin's Press.

Shimko, P. (2004). The optimal regulating of economic systems. Saint-Petersburg: Business-press.

Tiihonen, S. (2004). From Governing to Governance. A process of change. Tampere: Tampere University Press.

Vainstein, G. (2002). From new technologies to the new economy. International economy and international relationships (MEIMO) journal, №10.

Paper submitted

Paper accepted for publishing

Paper pubslihed on-line
28 September 2017

07 December 2017

01 February 2018 